\section{ECONOMICS}

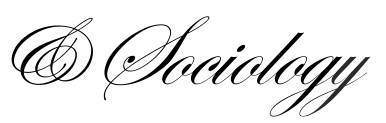

\title{
INEQUALITY AND GLOBALISATION: ANALYSIS OF EUROPEAN COUNTRIES
}

\author{
Celia Sánchez-López, \\ University of Huelva, \\ Spain \\ E-mail: celia.sanchez@dege.uhu.es
}

\author{
María Teresa Aceytuno, \\ University of Huelva, \\ Spain \\ E-mail: \\ maria.aceytuno@dege.ubu.es
}

Manuela A. De Paz-Bañez, University of Huelva,

Spain

E-mail:depaz@ubu.es

Received: February, 2019

1st Revision: June, 2019

Accepted: November, 2019

DOI: $10.14254 / 2071-$

789X.2019/12-4/5

JEL Classification: O15, O11, F16, J31

\begin{abstract}
This paper examines the relationship between income inequality and globalisation in 29 European countries over the period of 2005-2015, the period including phases of both growth and economic recession. Unlike other studies which analyse variations in inequality in specific countries or in both developed and developing economies, this study focuses on European countries, that is, high-income countries with highly developed economies. It investigates the influence on inequality exerted by trade and financial globalisation and technological development over the ten years through panel data multiple regression analysis. The results indicate that both trade globalisation and the degree of technological development are associated with reduction in inequality, while financial globalisation, and particularly foreign direct investment inward, are associated with increase in inequality. Furthermore, strong associations can be observed between the dimensions of the study in function of the average salaries and GDP per capita of different countries, reflected through partial correlations.
\end{abstract}

Keywords: income inequality, Gini index, globalisation, multiple regression analysis, ascending hierarchical classification.

\section{Introduction}

Income inequality in Europe is a dramatic and complex problem. Gini index in 2005 was 29,5 and reached 30,1 a decade later. Moreover, there are important differences between countries. Sánchez-López and de Paz (2016) analysed different responses of the European Union countries to poverty and income inequality and associated phenomena during the 20082014 period of recession. Their study has shown that in the last few years, most likely due to the impact of the economic crisis - at least in its early stages - on the economies of the developed world, there has been an increase in the number of studies into inequality and poverty in Europe. 
Initially, work in this area focussed on the interplay between employment and modes of labour activation, but more recently a number of academic studies have appeared which explore the relationship that poverty and income inequality sustain with macroeconomic variables defining globalisation. Providing empirical evidence for interplay between income inequality and globalisation makes it possible to contemplate global policies aimed at palliating inequality and poverty, which have been especially accentuated in certain European countries in the wake of the economic downturn. The question of up to what point globalisation positively or negatively affects inequality is far from simple, as the relationships between variables at both national and international levels of analysis are insulated from the effects of other variables. Furthermore, as Basu (2006:1362) pointed out, it is a question contingent upon the place as much as the time of carrying out the analysis: "First of all, it is too catch-all of a term and therefore it can be good and bad, depending on what aspect of it we are looking at, in which period and at which location". The fact that the relationship between inequality and globalisation is highly influenced by the socioeconomic conditions of the countries in question and their degree of economic development leads us to centre our analysis solely on developed countries, although we would not wish to obviate the fact that our trading partners enjoy differing degrees of economic development. It is also worth noting that there is a preponderance of studies into developing countries.

With these considerations in mind, this paper investigates the interplay between income inequality and various dimensions of globalisation across 29 European countries over the period of 2005-2015, a period covering both the times of economic growth and of economic recession. In contrast to other studies exploring variations in inequality in specific countries or across both developed and developing economies, this study focuses on European countries. There are three macroeconomic trends which are particularly relevant to the aims of this work: technological advances, and the processes of financial and trade globalisation. In this study the endogenous or dependent variable is income inequality after social transfers, given that the objective is to analyse the effect that increased or decreased trade and financial globalisation and technological development on the levels of inequality in developed countries.

In this regard, this paper has two aims: firstly, it seeks to contribute to the literature by analysing the effects of globalisation on income inequality in developed countries (in terms of the economy, finance and technology), given that, as Jaumotte Lall and Papageorgiou (2013) point out, there is no theoretical framework incorporating these effects into a model of income inequality, and very few studies which focus solely on developed countries; and secondly, it attempts to contrast our results with those obtained in other studies of a similar nature. Indeed, the only works we found that was focused on developed countries was that of Lang and Mendes Tavares (2018) and Pérez-Moreno and Angulo-Guerrero (2016), both of which, however, analysed just one dimension of globalisation, namely, economic globalisation. Lang and Mendes Tavares (2018) consider the impact of globalisation on the increase in inequality and economic growth in terms of the KOF Globalisation Index, while Pérez-Moreno and AnguloGuerrero (2016) explore the relationship between economic freedom and income inequality using two global measures of economic freedom, the Fraser Institute Index and the Heritage Foundation Index. In both cases, a positive relationship between income inequality and economic globalisation was established.

Following this introductory section, we present the theoretical framework, in which we differentiate the interactions between globalisation (in the three facets under study here) and income inequality. We then describe the methodology in terms of both specifications of the input data and the panel data model we apply. The fourth section provides a brief description of the cluster analysis applied to input data on inequality and trade, financial and technological 
globalisation in 29 countries. In the final section, we present the results, discussion and main conclusions.

\section{Literature review}

There is currently a large academic literature about the relationship between income inequality and globalisation, ranging from Piketty and Saez (2013), who question their possible interaction (and more specifically in the case of financial globalisation) and consider them as more coincidental in time than causal phenomena, to the more polarised positions of Goldberg and Pavcnick (2007), Dollar (2001), Winter, McCulloch, and McKay (2004), Wade (2004) and Ravallion (2001). Below we summarise the main approaches to explaining the interaction between trade, financial and technological globalization and income inequality.

\subsection{Trade globalisation and income inequality}

The Stolper-Samuelson theorem (an application of Heckscher-Ohlin trade theory to inequality) argues that an increase in international trade will, in the case of developing countries with a predominantly unskilled workforce, lead to an increase in the wages of the unskilled workforce, and a decrease in the income of the skilled workforce, thus contributing to a decrease in inequality. By contrast, in the case of developed countries, the theorem predicts the inverse, that is, an increase in international trade in which production is not predominantly unskilled, will lead to higher levels of inequality.

The theorem has informed many academic works (Dollar, 2001; Dollar and Kraay, 2004; Winter, McCulloch and McKay 2004; Jaumotte, Lall and Papageorgiou, 2013; Winters and Martuscelli 2014, amongst others) and has given rise to numerous empirical studies. However, there has been considerable disagreement over the validity of the theorem, with no general consensus being achieved even among the empirical studies of developing countries, which outnumber those of developed countries. Winter and Martuscelli (2014) provides a comprehensive literature review of the effects of trade liberalisation on poverty in developing countries. Although the authors accept the theoretical assumption that trade liberalisation benefits the reduction of poverty, they conclude that even today it is not possible to make any general conclusions about the relationship between trade liberalisation and poverty. Further discussion of Heckscher-Ohlin model can be found in Jaumotte Lall and Papageorgiou (2013:284), which reviews various studies arguing from different perspectives that it is incompatible with the experience of inequality throughout the world and not just that of developing countries. At the other extreme of the debate about the interplay between globalisation of trade and inequality are those works which either question the assumption that trade globalisation benefits inequality, or question whether any relation between the two exists at all (Piketty and Saez, 2013). These studies, both numerous and varied in their approaches, introduce new elements of analysis not considered in works of a more conventional nature. According to Jaumotte et al (2013), the difficulty of fitting empirical results to the conventional model (the Stolper-Samuelson theorem), has stimulated the growth in academic studies arguing in favour alternative approaches. One such example is the affirmation that reallocation of factors can take place within activity sectors and not between countries, as formulated by the $\mathrm{H}-\mathrm{O}$ model, which would condition the demand for skilled and unskilled labour in both the countries of origin and the destination countries. Wade (2004) notes that results can vary according to the units of measurement employed in the analysis of the institutional features of the countries under study. Various other papers have explored how the interplay between inequality and trade globalisation can be affected by a variety of micro and macro socio- 
economic variables, such as the labour-market conditions specific to each area regarding employment/unemployment, the specific features of production, the socio-institutional conditions pertaining, the effect of technology on the demand for unskilled and skilled labour, and the internationalisation of the financial sector, amongst other variables (Berman, Bound and Crillïches, 1994 in Jaumotte Lall and Papageorgiou, 2013; Goldberg and Pavnick, 2007; Wade 2004; Ravallion, 2001; Dollar and Kraay, 2002, among other studies).

\subsection{Technological progress and inequality}

According to the conventional scheme (Bernan, Bound, and Machin, 1998; Goldberg and Pavcnik, 2007), one of the factors frequently attributed to the increase in inequality is the decline in demand for unskilled compared to skilled labour in relation to the increase in skill premium (the ratio of the wages of skilled workers to those of unskilled). Hence, as Borondo, Herrera and Jiménez (2011:7) state, "the traditional theoretical scheme for explaining the increase in inequality is the relative supply and demand of skills. An increase in the relative supply (ratio of skilled to unskilled workers) reduces the skill premium and consequently inequality, while an increase in the relative demand has the opposite effect". Hence, the increase in demand for skilled compared to unskilled workers as a result of technological progress can be explained by three main approaches. The first, based on the Heckscher-Ohlin model of comparative advantage and the subsequent development within this model of the StolperSamuelson theorem, predicts that technological progress increases demand for skilled labour and reduces that of unskilled (and their corresponding salaries) in developed countries, thus leading to an increase in inequality, whilst having the opposite effect in undeveloped or developing countries. This model, resting on an excessively restrictive hypothesis, has not found support in a large number of empirical studies (Jaumotte Lall and Papageorgiou, 2013). A second approach, which does away with the assumption of identical production technology between countries and starts instead from a recognition that developed countries might have varying levels of technology, and that, beyond exchanges of labour and capital, technology itself might be diffused between developed and developing countries. This hypothesis, known as the Skill-Biased Technological Change (SBTC), considers that developments in production technology are biased in favour of skilled jobs to the detriment of unskilled ones, a phenomenon affecting both developed and developing countries (Goldberg and Pavcnik, 2007; and Borondo, Herrera and Jiménez, 2011; Berman, Bound and Machin, 1998). There are a number of ways by which technological progress favours a more skilled workforce (Hornstein et al. 2005 in Borondo, Herrera and Jiménez 2011:8), at least in developed countries (the object of study in this paper). The first of these is the fact that capital and skills tend to complement each other, given that technological advances tend to result in more intensive use of capital, whilst exploitation of capital requires skills, thus increasing its relative demand (Goldberg and Pavcnik 2007:63). The second is that the transference of technologies between countries naturally requires, at least in the early stages of adoption, a higher demand for an appropriately skilled workforce among the receiving companies. Finally, there is the factor of each worker's own interests in developing their skills in using the new technology. Although the SBTC model is more widely accepted than the Stolper-Samuelson regarding exposure to trade in developing countries (Bernan, Bound, and Machin 1998: 1246), both consider that technological globalisation increases the skill premium and hence inequality. There seems to be general agreement that an increase in the skill premium (as a result of technological globalisation) increases demand for more skilled workers, although this assumption has been questioned (Goldberg and Pavcnik, 2007:58). Finally, a third approach to explaining how technological globalisation affects inequality makes reference to the fact that technological changes lead to a 
more intense use of the factors of production (labour and capital), increasing the performance of capital on labour (Krusell at al., 2000). In this respect, the theory starts from the assumption that, by increasing the intensity of capital (associated with technological progress), the diffusion of technological change leads to a greater increase in the relative income of the owners of the capital resources compared to the increase in the remuneration of the labour factor, hence negatively affecting inequality. In this case, technological progress could imply an increase in inequality.

\subsection{Financial globalisation and inequality}

With respect to financial globalisation, and taking into consideration only those empirical studies using foreign direct investment (henceforth FDI) as the reference variable as opposed to more short-term financial elements, the effect of financial globalisation on inequality seems clearer than in the case of the preceding variables, although it has not been fully empirically demonstrated (Jaumotte Lall and Papageorgiou, 2013). Nevertheless, one of the assumptions of the Stolper-Samuelson model is violated since capital is considered to be mobile not only within a country but internationally and its conclusions are weakened, given that FDI typically targets highly skilled sectors (Jaumotte et al., 2013), increasing the demand for skilled labour even in developing countries. However, these conclusions may differ in that what might be a high-skilled inward FDI may not be so highly skilled in the economy originating the FDI. In this case, the initial technological level and the national socio-productive and institutional characteristics could exert a great influence on the interplay between inequality and financial globalization.

In summary, the influence over the increase in inequality exerted by macroeconomic changes, and specifically the globalisation of trade and finance, along with technological progress, is in the ultimate instance associated with the variation in the volume of employment and wages associated with low-skilled work. However, the empirical findings from the studies carried out are conclusive in all cases. It is possible that the interaction between dimensions becomes another element in the analysis itself and affects the results. In the following sections we describe the explanatory model underpinning this study of the interplay between globalisation, in its three aspects, and income inequality, with the aim of shedding light on this relationship in developed countries.

\section{Methodological approach}

In contrast to other studies, which focus on longitudinal analysis of inequality in a specific country, in this study we analyse income inequality in different European countries over the period 2005-2015, including both periods of economic growth and economic decline. The measure of income inequality used here is the Gini index, after social transfers.

For this study of globalisation, and aware of the breadth of the concept and the variety of phenomena which can reflect a greater or lesser economic interdependence between countries, we will limit our discussion exclusively to three specific components: trade globalisation, financial globalisation and technological progress and advances. In this regard, and with the object of being able to compare our results with those obtained in other comparable and widely disseminated studies of the last few years, we draw on, so far as it has been possible to find the information, the indicators used by Jaumotte, Lall and Papageorgiou (2013), updated to the years of the study and only for European countries. By this means, we eliminate the mirror effect which can occur by including countries with very different levels and stages of development. 
The study concerns the period 2005-2015, determined by the availability of data and the desire to take a period covering a complete economic cycle. Certain key variables, such as imports and exports relating to GDP, were only available in a standardised format from 2005 as a result of methodological changes in certain countries. Furthermore, the income inequality index, the dependent variable, was not available for certain countries - specifically certain Eastern European countries - before 2005.

\subsection{Data specifications}

For this study of income inequality we used Gini index data after social transfers, from the income and quality of life survey by the European Union Statistical Office (henceforth Eurostat), which measures the degree to which income distribution within a specific country diverges from an equal distribution. Although alternative indicators can be used to measure income inequality, we use Gini index in order to make our results comparable to those published in the literature, focused, for instance in analyzing the relationship between income inequality and trade, financial and technological globalization.

To configure the trade globalisation construct, we used the proportion of each country's total volume of trade (imports and exports) to its GDP drawn from the annual national accounts also available at Eurostat. For the financial globalisation construct we used foreign direct investment data (inward and outward) as a percentage of GDP, freely available at the World Bank and International Monetary Fund. For the technological progress construct we looked at the proportion of both high-tech to total exports (using the statistics on high-tech at Eurostat) and knowledge-intensive services to GDP, this latter using the table of Digital Agenda Indicators of information and communication technologies (ICT) usage for measuring European digital technology progress, in fulfilment of the objectives of the Europe 2020 Initiative, the Digital Agenda for Europe (more specifications see Table 2 annex).

The election of control variables has been guided by the previous literature - see, for instance, Jaumotte et al. (2013), Lang and Medes Tavares (2018) or Rojas-Vallejos and Turnovsky (2017) -which led us to build our theoretical framework identifying the three dimensions of the globalization process. So, we included: GDP per capita, the gross enrolment ratio for elementary education, the proportion of unskilled labour to total employment figures, and mean annual salary - all available at Eurostat.

In addition to the set of variables described above, we draw on a database covering 29 European countries over the period 2005-2015. Initially we started with the countries making up the European Economic Area, but as the data for the majority of the indicators were unavailable for Iceland and Liechtenstein, we finally opted for the EU plus Norway. Due to the fact that we do not have data for some variables and countries in particular years, the sample is constricted to 156 values. Even starting from a sufficiently broad frame of analysis, the number of final data points was markedly reduced. This illustrates the major issue of missing data in this type of study. We avoided any kind of data imputation in order to avoid having to impose more restrictions on the model. Nevertheless, and consistent with the results described in the following section, we can consider the size of the sample to be appropriate to the number of independent variables used in the analysis, given that R2a is very close to R2 (Cea D'Ancona, 2011).

\subsection{Specifications of the model}

In carrying out the study we combined different methods: biplot analysis combined with ascending hierarchical classification analysis and multiple regression analysis of panel data. 
The application of biplot analysis reduces the dimensionality of the original data enabling to a better understanding of the relationship between variables over time. We use the representation technique $\mathrm{HJ}$-Biplot to obtain a high quality representation of them.

The biplot analysis combined with ascending hierarchical classification analysis by Ward method allows us to establish clusters of countries on the basis of three main variables: GDP per capita, the percentage of the population in employment in the 16-64 age range, and the mean annual salary. By means of this, we identify three clusters of countries with similar socioeconomic and productive characteristics. It allows us to develop a comprehensive descriptive analysis of globalization and inequality evolution of the European countries that to our knowledge would not be possible without applying clusterization techniques.

Similarly, the use of HJ-biplot combined with cluster analysis allows us to summarize and describe the income inequality evolution in several countries and years, although it is difficult to identify shared patterns between them, as it is shown in the Annex.

The panel data multiple regression analysis is based on the following specification of fixed effects:

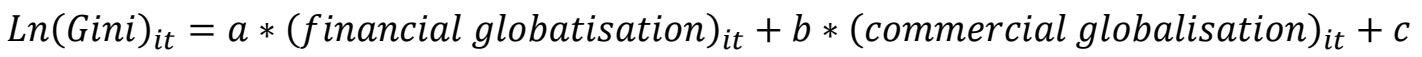

$$
\begin{aligned}
& *(\text { technologycal globalisation })_{i t}+\delta *(\text { control variables })_{i t}+\eta_{i}+\theta_{t}+\varepsilon_{i t}
\end{aligned}
$$

Where globalisation is divided into three measures: trade, financial and technological. There is an additional factor which includes the control variables: proportion [peso] of unskilled labour, gross enrolment ratio (elementary), employment rate of 15-64 year-olds, and mean annual salary (pps). The terms $\eta$ i y $\theta t$ represent a complete set of dummy variables for countries and year, respectively, and $\xi$ it captures all the omitted factors.

\section{Empirical analysis}

\subsection{Background}

In this section, we give a brief descriptive statistics of the main variables representative of trade and financial globalisation, and of technological progress and the income inequality before the regression analysis. We do not study evolution but differences between groups. To carry out the analysis, we categorised the 29 European countries into three groups obtained from applying an ascending hierarchical classification analysis based on three fundamental variables: the mean annual salary (pps), the GDP per capita, and the employment rate of 15-64 year-olds. The resulting clusters were as follows (Table 2 in Annex shows the main descriptive statistics of the clusters):

- Cluster 1 (9 countries). Luxemburg, Norway, the Netherlands, Austria, Sweden, Denmark, Germany, Finland and the United Kingdom. These are the countries with the largest gross domestic product per capita, the highest average salary, and the highest rate of employment among the age range 16 to 65 in the period of analysis.

- Cluster 2 (8 countries). Belgium, France, Cyprus, Greece, Ireland, Italy, Malta and Spain make up the group of European countries with mid-range values in GDP per capita, mean annual salary and employment rate. France, Ireland and Cyprus had certain values similar to the countries in cluster 1 , but on balance were finally included in this cluster. Cyprus was found to have average salaries above those of France and Germany in the period 2005-2015, but its GDP per capita situated it closer to the cluster 2 countries. Ireland and France gave a similar picture, but although their GDP and average 
salaries were higher than the other countries in this group, their employment rates were medium to low.

- Cluster 3 (12 countries). Bulgaria, Croatia, the Czech, Estonia, Hungary, Latonia, Lithuania, Poland, Portugal, Rumania, Slovakia and Slovenia make up this group of countries with mean annual salaries and GDP per capita below the European average. Nevertheless, in certain cases, the employment rate of 15 to 64 year-olds was above that of many countries in cluster 2 .

Taking into account this classification, Figure 1 below shows the average values by cluster for income inequality, imports and Export-to-GDP ratio, the ICT sector (\% GDP), and inward and outward direct foreign investment (DFI) (\% GDP).

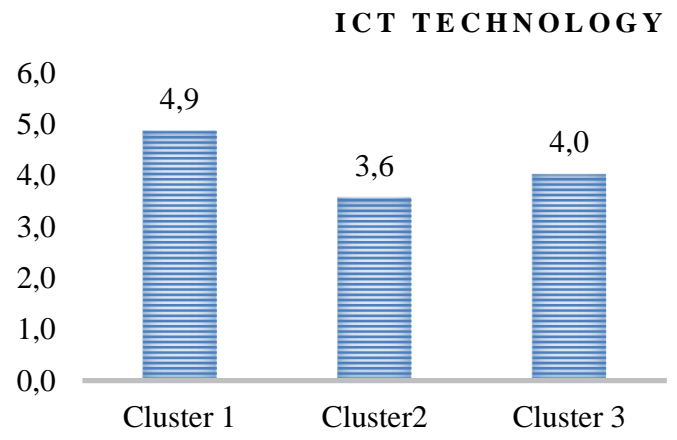

E X P O R T S

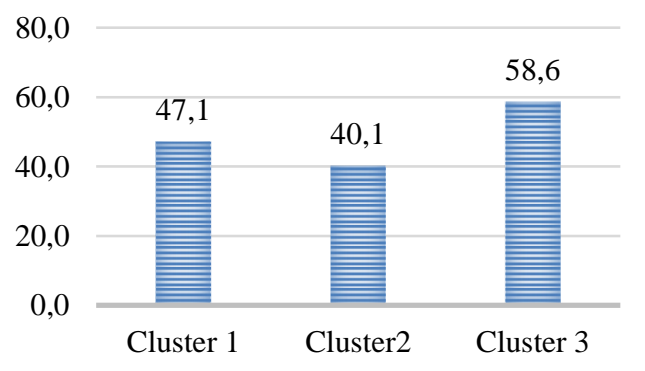

I M P O R T S

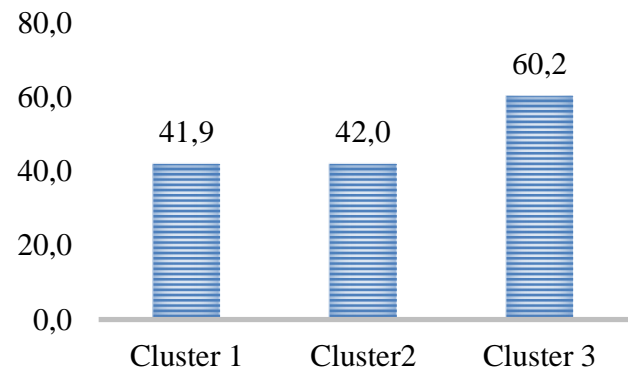

INCOME INEQUALITY

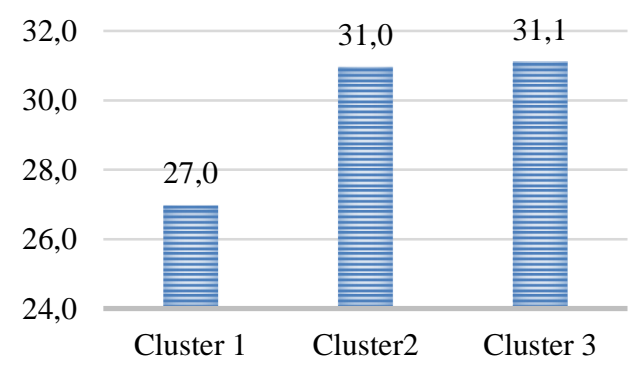

F D I O UT W A R D

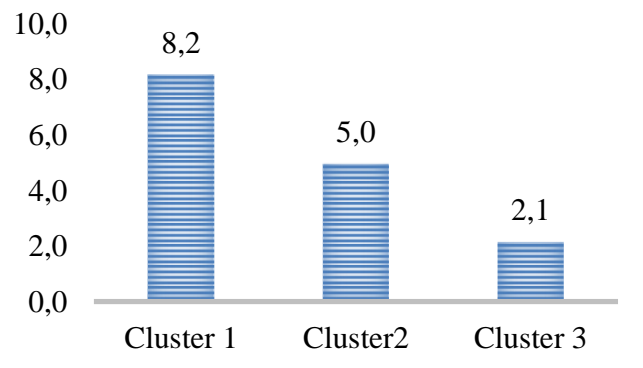

F D I I N W A R D

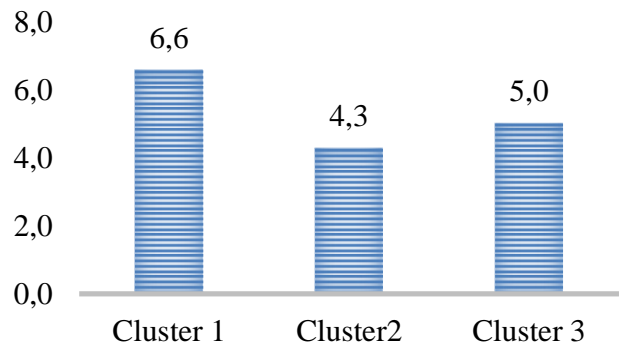

Figure 1. Comparative charts showing the main variables by cluster. Average values by cluster Note: Own computations.

(Luxembourg and Ireland were excluded from the descriptive because they distorted the average values of their respective groups. Both countries had very high figures for both DFI (inward and outward) and the ratio of imports and exports to GDP, with large year-on-year fluctuations).

As can be seen in Figure 1, the average income inequality is very high in all three clusters. Those with the highest levels of inequality are clusters 2 and 3, with mean inequality indices for the period of around $31 \%$, while cluster 1 has a figure of $27 \%$. With respect to trade 
globalisation, the clusters with the highest openness index (the ratio of imports plus exports to GDP) are clusters 3 and 1 in that order, these also being the clusters with highest and lowest inequality respectively. Imports and exports over GDP are highest among those countries in the group with the lowest average salary and GDP per capita, namely cluster 3.

Regarding technological globalisation, clusters 1 and 3 have, in this order, higher ratios for the ICT sector as a whole than cluster 2. Finally, with respect to the last dimension in the study, financial globalisation, the high direct foreign investment in cluster 1 stands out against the others in terms of both inward and outward DFI.

Furthermore, there are large differences between countries within the same cluster, such that the range of income inequality in cluster three exceeds 12 points (see Table 2 Annex).

It is difficult to make any generalisations about the patterns of relationships between income inequality and globalisation, even within the framework of the economic clusters which were established. For example, there are countries in cluster 1 which, even though they show moderate growth in GDP per capita over the period of study, show quite different patterns of development in terms of income inequality, and varying levels of trade and financial openness. Such is the case, among others, of Norway and the Netherlands. Norway, with trade, technological and financial openness indices below the average in its group, had a Gini index of $28.2 \%$ in 2005 , which it saw reduced to $23.9 \%$ by 2015 . By contrast, the Netherlands, with mid-to-high rates of trade openness, witnessed almost no reduction in its Gini index, which went from $27.6 \%$ in 2005 to $26.7 \%$ in 2015 . In cluster 2, Belgium stands out as a country which, despite having inequality indices below the average in its group, high rates of trade, financial and technological openness, and significant growth in GDP per capita, only managed to reduce its inequality index by two points between 2005 and 2015. In summary, as suggested above, it is possible that the variables at both the intranational and international levels are affected by other variables or interactions between them. If such be the case, a multiple regression analysis can help us to find any interaction or general behavior patterns.

\subsection{Results of the regression analysis}

The results of the regression analysis are shown below (see Table 1).

We started with a complete model (Model 1) with the [reference] measures for each aspect of globalisation and the control variables described in the methodological section. Trade globalisation included the variables ratio of imports to GDP and a global measure of the ratio of exports and imports to GDP. The ratio of exports to GDP was excluded from the analysis as it exhibited a high degree of multicollinearality with the ratio of imports to GDP. Technological globalisation included the ratio of ICT to GDP and high-tech products to total exports. This latter variable, however, did not achieve any degree of significance to the model (see Table 1). Financial globalisation made use of the ration of both inward and outward direct foreign investment to GDP. The control variables were the gross enrolment ratio for elementary education, the proportion of unskilled to total workforce, the employment rate in the working age population (16-64) and the mean annual salary PPS. GDP per capita was eliminated from the study as it had a high correlation with mean salary. Just to be certain, we repeated the analysis, first with mean salary, then with GDP per capita, and obtained practically identical results. 
Table 1. Income inequality panel regressions. Model specifications

\begin{tabular}{|c|c|c|c|c|c|}
\hline Model specifications & Model 1 & $\begin{array}{l}\text { Base } \\
\text { model }\end{array}$ & Model 2 & Model 2A & Model 2B \\
\hline \multicolumn{6}{|l|}{ Trade globalisation } \\
\hline Import-to-GDP ratio & $\begin{array}{c}-0.314 * * * \\
(0.026)\end{array}$ & $\begin{array}{c}-0.206 * * * \\
(0.023)\end{array}$ & $\begin{array}{c}-0.251 * * * \\
(0.025)\end{array}$ & $\begin{array}{c}-0.406 * * * \\
(0.026)\end{array}$ & $\begin{array}{c}-0.407 * * * \\
(0.026)\end{array}$ \\
\hline $\begin{array}{l}\text { Ratio of exports and imports to } \\
\text { GDP }\end{array}$ & $\begin{array}{c}-0.249 * * * \\
(0.095)\end{array}$ & $\begin{array}{c}-0.513 * * * \\
(0.068)\end{array}$ & $\begin{array}{c}-0.262 * * * \\
(0.071)\end{array}$ & $\begin{array}{l}-0.123 \\
(0.072)\end{array}$ & $\begin{array}{l}-0.120 \\
(0.073)\end{array}$ \\
\hline \multicolumn{6}{|l|}{ Technological globalisation } \\
\hline Ratio of ICT sector to GDP & $\begin{array}{c}-0.281 * * * \\
(0.041) \\
\end{array}$ & $\begin{array}{c}-0.238 * * * \\
(0.031) \\
\end{array}$ & $\begin{array}{c}-0.188 * * * \\
(0.026) \\
\end{array}$ & $\begin{array}{c}-0.190 * * * \\
(0.024) \\
\end{array}$ & $\begin{array}{c}-0.195 * * * \\
(0.026) \\
\end{array}$ \\
\hline High-tech exports & $\begin{array}{l}-0.055 \\
(0.020)\end{array}$ & - & - & & \\
\hline \multicolumn{6}{|l|}{ Financial globalisation } \\
\hline Inward DFI & $\begin{array}{l}0.355^{* * *} * \\
(0.011)\end{array}$ & $\begin{array}{c}0.195 * * * \\
(0.009)\end{array}$ & $\begin{array}{c}0.194 * * * \\
(0.008)\end{array}$ & $\begin{array}{c}0.025 \\
(0.008)\end{array}$ & $\begin{array}{c}0.025 \\
(0.009)\end{array}$ \\
\hline Outward DFI & $\begin{array}{l}-0.294 * * * \\
(0.009)\end{array}$ & $\begin{array}{c}-0.220 * * * \\
(0.008)\end{array}$ & $\begin{array}{c}-0.278^{* * * *} \\
(0.007)\end{array}$ & $\begin{array}{l}-0.042 \\
(0.009)\end{array}$ & $\begin{array}{l}-0.043 \\
(0.009)\end{array}$ \\
\hline \multicolumn{6}{|l|}{ Outward/inward DFI } \\
\hline \multicolumn{6}{|l|}{ Control variables } \\
\hline $\begin{array}{l}\text { Percentage of unskilled labour } \\
\text { in total labour force }\end{array}$ & & & $\begin{array}{c}0.519 * * * \\
(0.031)\end{array}$ & $\begin{array}{c}0.532 * * * \\
(0.029)\end{array}$ & $\begin{array}{c}0.536^{* * *} \\
(0.029)\end{array}$ \\
\hline Gross enrolment ratio (primary) & & & $\begin{array}{c}-0.207 * * * \\
(0.028)\end{array}$ & $\begin{array}{c}-0.210 * * * \\
(0.026)\end{array}$ & $\begin{array}{c}-0.204 * * * \\
(0.027)\end{array}$ \\
\hline Mean annual salary (pps) & & & & $\begin{array}{c}-0.431 * * * \\
(0.024)\end{array}$ & $\begin{array}{c}-0.443 * * * \\
(0.027)\end{array}$ \\
\hline $\begin{array}{l}\text { Employment rate of working } \\
\text { age population (16-64) }\end{array}$ & & & & & $\begin{array}{c}0.018 \\
(0.089)\end{array}$ \\
\hline R-squared & 0.471 & 0.533 & 0.666 & 0.715 & 0.715 \\
\hline Adjusted R-squared & 0.447 & 0.517 & 0.650 & 0.700 & 0.698 \\
\hline
\end{tabular}

Source: own compilation.

$* * *$ denotes a $1 \%$ level of significance. All variables are taken as natural logarithms

All key assumptions of multiple regression analysis are met. The model is robust and all variables in the model have been log transformed to accomplish the assumption of normality.

The base model or reference model comprised the significant variables from Model 1. Both the standard error and R2 coefficient, and hence the fit of the model, significantly improve when the non-significant independent variables from Model 1 are excluded. The estimation of the new model (base model) has a significant impact on income inequality. There is a significant linear relationship between inequality and the set of independent variables in the analysis. The independent variables explain around $50 \%$ of the variance in the dependent variable $(44.7 \%$ for Model 1 and 51.7\% for the base model). Both trade globalisation and technological progress have a statistically negative effect, that is to say, a reduction on inequality. However, in the case of financial globalisation, an increase in inward direct foreign investment results in an increase in inequality, while outward DFI has a similar impact to that of trade and technology globalisation.

In addition to the significant variables from the base model, models 2, 2A and 2B (Table 1) also include control variables reflecting the socio-economic and educational peculiarities of the different countries. These were introduced progressively so the effect of each in relation to the base model. Model 2 includes the control variables proportion of unskilled to total 
workforce, and the gross enrolment ratio (elementary). All the variables, including the control variables, were significant, and the share of the variance markedly increases with respect to the base model (66.6\%). Model 2A adds a further control variable, mean annual salary. The change in the $\mathrm{F}$ value is significant and the adjusted R2 coefficient increases 0.049 points. However, the two variables comprising the financial globalisation dimension and the trade-to-GDP variable (combined exports and imports over GDP, see Table 1) lose their significance. The same tendency results from introducing GDP per capita in the place of mean annual salary. Finally, the inclusion in model 2B of employment rate (in the range 16-24), does not result in a significant change in the $\mathrm{F}$ value, nor an improvement in the goodness of fit of the model. This outcome could have been due to a spurious relationship or constraining effect of the control variables, for which reason we analysed the zero-order partial and semipartial correlations.

Table 2. Correlations between inequality and the remaining independent variables by model

\begin{tabular}{|c|c|c|c|c|}
\hline \multirow{2}{*}{\multicolumn{2}{|c|}{ Model }} & \multicolumn{3}{|c|}{ Correlations } \\
\hline & & Zero order & Partial & Part \\
\hline \multirow{6}{*}{ 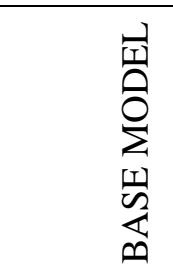 } & \multicolumn{4}{|l|}{ (Constant) } \\
\hline & Import-to-GDP ratio & -0.122 & -0.257 & -0.182 \\
\hline & Trade-to-GDP ratio & -0.634 & -0.551 & -0.452 \\
\hline & Ratio of ICT sector to GDP & -0.389 & -0.291 & -0.208 \\
\hline & Outward FDI & -0.397 & -0.234 & -0.164 \\
\hline & Inward FDI & 0.013 & 0.201 & 0.140 \\
\hline \multirow{8}{*}{ 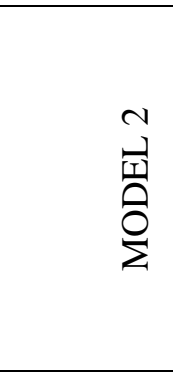 } & (Constant) & & & \\
\hline & Import-to-GDP ratio & -0.122 & -0.285 & -0.172 \\
\hline & Trade-to-GDP ratio & -0.634 & -0.309 & -0.188 \\
\hline & Ratio of ICT sector to GDP & -0.389 & -0.269 & -0.162 \\
\hline & Outward FDI & -0.397 & -0.324 & -0.198 \\
\hline & Inward FDI & 0.013 & 0.234 & 0.139 \\
\hline & Gross enrolment ratio (primary) & 0.238 & -0.225 & -0.133 \\
\hline & $\%$ of unskilled workforce & 0.641 & 0.533 & 0.364 \\
\hline \multirow{9}{*}{$\begin{array}{l}\overleftrightarrow{\lambda} \\
\text { 䎡 } \\
\stackrel{0}{\Sigma}\end{array}$} & (Constant) & & & \\
\hline & Import-to-GDP ratio & -0.122 & -0.426 & -0.251 \\
\hline & Trade-to-GDP ratio & -0.634 & -0.149 & -0.081 \\
\hline & Ratio of ICT sector to GDP & -0.389 & -0.293 & -0.163 \\
\hline & Outward FDI & -0.397 & -0.045 & -0.024 \\
\hline & Inward FDI & 0.013 & 0.029 & 0.016 \\
\hline & Gross enrolment ratio (primary) & 0.238 & -0.245 & -0.135 \\
\hline & $\%$ of unskilled workforce & 0.641 & 0.573 & 0.373 \\
\hline & Mean annual salary (PPS) & -0.476 & -0.383 & -0.221 \\
\hline \multirow{10}{*}{ 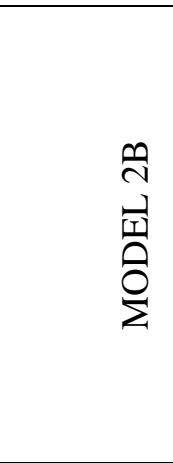 } & (Constant) & & & \\
\hline & Import-to-GDP ratio & -0.122 & -0.426 & -0.251 \\
\hline & Trade-to-GDP ratio & -0.634 & -0.144 & -0.077 \\
\hline & Ratio of ICT sector to GDP & -0.389 & -0.283 & -0.158 \\
\hline & Outward FDI & -0.397 & -0.046 & -0.024 \\
\hline & Inward FDI & 0.013 & 0.030 & 0.016 \\
\hline & Gross enrolment ratio (primary) & 0.238 & -0.232 & -0.127 \\
\hline & $\%$ of unskilled workforce & 0.641 & 0.568 & 0.368 \\
\hline & Mean annual salary (PPS) & -0.476 & -0.357 & -0.204 \\
\hline & Employment rate (15-64 year-olds) & -0.506 & 0.023 & 0.012 \\
\hline
\end{tabular}

a. Dependent variable: GINI. All data are taken as natural logarithms.

Source: Authors' computations. 
Table 2 below shows the partial and semipartial correlation coefficients together with the zero order correlations - the correlation coefficients calculated without taking into account the presence of a third variable. Comparison of these coefficients suggests some interesting patterns of relationships.

As we will see in the next section, the results of the empirical analysis contribute several elements we regard as relevant to the literature on the determinants of income inequality in developed countries. Hence, although the relative weight of the different globalisation dimensions are more or less in balance, various interesting interactions can be seen which alter the magnitude of the relationship of each dimension to inequality. This phenomenon is also evident when we analyse the partial and semipartial correlations in Table 3, as we will see below.

Finally, with the intention of testing the robustness of the model and capturing potential heterogeneities among countries or over time, we applied different fixed effects models individual, temporal, and within - and also a random effects model. The results were conclusive only for the temporal fixed effects model. The results are shown in Table 3 below. It can be seen that the relationships between inequality and globalisation in the various dimensions studied here are maintained. Nevertheless, significant differences can be observed for the years 2013, 2014 and 2015, which coincide with the economic crisis (the explanatory causes of this results are not clear and are beyond the purpose of this paper. Nevertheless, they can be further explored in the future).

Table 3. Inequality Income Panel Regressions (Dependent variable: natural logarithm Gini)

\begin{tabular}{lllll}
\hline & Estimate & Std. Error & T value & $\operatorname{Pr}(>/ \mathrm{t} /)$ \\
\hline (Intercept) & 1,633107 & 0,038073 & 42,894 & $<2 \mathrm{e}-16^{* * *}$ \\
\hline Ratio of ICT sector to GDP (\% GDP) & $-0,073944$ & 0,029538 & $-2,503$ & $0,013276^{*}$ \\
\hline Inward FDI (\% GDP) & 0.039280 & 0,008620 & 4,557 & $1 \mathrm{e}-05^{* * *}$ \\
\hline Outward FDI (\% GDP) & $-0,018321$ & 0,007127 & $-2,571$ & $0,011030^{*}$ \\
\hline Import-to-GDP ratio (\% GDP) & $-0,083100$ & 0,021820 & $-3,808$ & $0,000197^{* * *}$ \\
\hline Trade-to-GDP ratio (\% GDP) & $-0,611644$ & 0,061777 & $-9,901$ & $<2 \mathrm{e}-16^{* * *}$ \\
\hline factor(AÑO)2006 & $-0,007800$ & 0,015053 & $-0,518$ & 0,604822 \\
\hline factor(AÑO)2007 & $-0,018198$ & 0,014417 & $-1,262$ & 0,208634 \\
\hline factor(AÑ)2008 & $-0,013855$ & 0,014096 & $-0,983$ & 0,327116 \\
\hline factor(AÑO)2009 & $-0,005241$ & 0,014685 & $-0,357$ & 0,721648 \\
\hline factor(AÑ)2010 & 0,006826 & 0,014098 & 0,484 & 0,628884 \\
\hline factor(AÑ)2011 & 0,009619 & 0,014379 & 0,669 & 0,504452 \\
\hline factor(AÑ)2012 & 0,014539 & 0,014953 & 0,972 & 0,332310 \\
\hline factor(AÑO)2013 & 0,034612 & 0,015995 & 2,164 & $0,031907 *$ \\
\hline factor(AÑ)2014 & 0,047927 & 0,015696 & 3,054 & $0,002637^{* *}$ \\
\hline factor(AÑO)2015 & 0,046015 & 0,0177925 & 2,567 & $0,011143^{*}$ \\
\hline Residual standard error & 0,04027 on 165 degrees of freedom & \\
\hline Multiple R-squared & 0,5861 & & \\
\hline Adjusted R-squares & 0,5484 & & \\
\hline F-statistic & 15,57 & & \\
\hline p-value & $2,2 \mathrm{e}-16$ & & \\
\hline
\end{tabular}

Source: own compilation 


\section{Discussion}

The variables relating to trade and technological globalisation - and in the case of financial globalisation, outward DFI - exhibited an inverse relationship with inequality. Only inward DFI covaried in the same direction as inequality. Even when the control variables were introduced the direction of the relationships was maintained across all models, although the relative weight of each did vary. We examine each dimension in detail below.

In the case of trade globalisation, our study suggests that increased trade globalisation (a higher ratio of imports and exports to GDP) is likely to reduce inequality. As heterodox economics argues, increased international trade can trigger reallocation of the factors of production, not only at an international level, but also between economic sectors, and a shift in productive activity towards sectors with higher wages. In this respect the results are consistent with those of Jaumotte Lall and Papageorgiou (2013) regarding developed countries, and also with Rojas-Vallejo and Turnovsky (2017) and Winters, McCulloch and McKay (2004), among others, who do not support the position that trade liberalisation has an adverse effect on inequality.

With respect to financial globalisation, while outward DFI reduces inequality, inward DFI increases it. An increase of $1 \%$ in outward DFI (holding constant all other variables) results in a $2.4 \%$ decrease in inequality, while the same increase in inward DFI conversely results in a $2.4 \%$ increase. These results are similar to those obtained by Jaumotte Lall and Papageorgiou (2013), in which inward DFI, the only significant variable, maintained a positive relationship with inequality, that is the greater the inward DFI, the greater the inequality.

Finally, regarding technological development, our results diverge from those of other studies which find that technological progress accelerates income inequality as it increases the skill premium and tends to replace the unskilled workforce. Our study found the inverse to be the case and that technological progress - insofar as developed countries are concerned reduces inequality. A possible explanation for this is that extensive use of new technologies in emerging sectors generates a sufficient number of opportunities productive enough to impact on other sectors, which despite being less specialised supply the requirements of the former in one way or another. Nevertheless, this is an aspect which requires further study into the import and export of new technologies and the effect on the countries involved.

Hence, in general terms, unlike the results of empirical analyses such as Jaumotte, Lall and Papageorgiou (2013), which find technological change to be the main determinant of (in this case, widening) inequality, in our study the dimension with greatest influence on income inequality is trade globalisation, followed by technological and financial globalisation.

It is worth noting the results obtained when the control variables were included in the models. Thus, for example, the inclusion of the gross enrolment ratio at elementary level and the proportion of unskilled workforce (Model 2), reduces the influence of the trade-to-GDP ratio and the proportion of the ICT sector to GDP. Likewise, the inclusion of mean annual salary in Model 2A results in a significant decrease in the influence of the variables in the financial globalisation domain (namely, inward and outward DFI). These effects could be a reflection of the important role in inequality played by the socio-economic factors of the different countries involved in the study, in particular average salary.

At the same time, there are also interesting results from the analysis of zero order, partial and semipartial correlations in the different models (Table 2). First, there would appear to be some moderation and even mediation in play, both between dimensions and between each dimension and income inequality, which could also explain the change in influence of the regression coefficients when new variables were introduced into the model. Hence, as reflected in Table 32, the relationship between the variables concerning trade globalisation and inequality 
varies significantly when we remove the effect of third variables from the relationship. Thus, in the case of the trade-to-GDP ratio, the correlation with inequality is notably reduced when we remove the effect of third variables from the relationship, in terms of both independent and dependent variables. This could be pointing to a potential interaction between trade globalisation and other globalisation dimensions included in the analysis. Furthermore, this tendency becomes more accentuated when we include in the analysis the control variables concerning the socio-economic situation, especially average salary (Model 2A), an effect which could suggests that the relationship between inequality and trade-to-GDP ratio could be moderated by other variables. The same tendency can be seen in the variable from the technological dimension.

In summary, the results of the empirical analysis of developed countries indicate that far from having a negative effect on inequality, globalisation can contribute to reducing it. Only inward DFI causes an increase in inequality.

\section{Conclusion}

The results of this study, which set out to analyse the effects of technology and trade and financial globalisation on income inequality in developed countries, indicate interesting relationships regarding areas of study directed towards reducing inequality. Although conventional approaches argue that both globalisation - in terms of trade and finance - and technology contribute to an increase in inequality, at least with regards to developed countries, this study finds rather different linkages. Only inward DFI has a direct relationship with income inequality, possibly as a result of a potential decrease in the demand for unskilled as opposed to skilled labour, or an increase in the skill premium. This possibility, however, is currently no more than a hypothesis, and calls for a deeper analysis of the productive sectors and the features of these affected by inward DFI in both the country of origin and the destination country. In this respect, comparing our results with those of Jaumotte et al. (2013), the only point on which our findings are in agreement with theirs is regarding the relationship between income inequality and trade globalisation and inward DFI, that is, both sets of results, suggest that an increase in trade globalisation and inward DFI results in a narrowing of inequality in developed countries. Otherwise, unlike the results of Jaumotte, Lall and Papageorgiou (2013), which find the main determinant of change in inequality (here an increase) to be technological change, ours find it to be trade globalisation, followed by technological and financial globalisation.

In addition, our results clearly show that the relationship between globalisation and inequality cannot be accounted for in isolation without taking into account potential interactions between dimensions, on the one hand, and the socio-productive and technological conditions of the countries in question, on the other. Indeed, as Crettaz (2013) concludes in his study into working poverty, it is possible that although the macro-economic effects on inequality are the same for most developed countries, they do so by different means. This consideration suggests an area of research for future studies, taking into account both interactions between constructs and the inclusion in the analysis of variables which reflect not so much the economic situation of the countries involved as the socioeconomic circumstances of individual households or family units, given the importance of mean annual salary in the results. Such as analysis, depending on the availability of information, could be carried out both within a framework of countries of similar degrees of economic development and productive structures and in specific countries using longer time series. 


\section{References}

Basu, K. (2006). Globalization, Poverty, and Inequality: What is the Relationship? What can be done?. World Development, 34(8), 1361-73.

Bernan E., Bound J., \& Machin S. (1998). Implications of Skill-Biased Technological Change: International Evidence. The Quarterly Journal of Economics, 113(4), 1245-79.

Borondo Arribas, C., Herrera Revuelta, J., \& Jiménez-Ridruejo Z. (2011). La Inversión en Nuevas Tecnologías y Distribución de la Renta: El caso de los Países del Este de Europa. XIII Reunión de Economía Mundial. Universidad del País Vasco. San Sebastián.

Crettaz, E. (2013). A State-of-the-Art Review of Working Poverty in Advanced Economies: Theoretical Models, Measurement Issues and Risk Groups. Journal of European Social Policy, 23(4), 347-62.

Cea D'Ancona, M.A. (2011). Análisis Multivariante. Teoría y Práctica en la Investigación Social, Madrid: Síntesis.

Dollar, D. (2001). Is Globalization Good for your Health?. Bulletin of The World Health Organization, 79(9), 827-33.

Dollar, D., \& Kraay A. (2002). Growth Is Good for the Poor. Journal of Economic Growth, 7, 195-25.

Dollar D., \& Kraay A. (2004). Trade, Growth, and Poverty. The Economic Journal, 114, F22F49.

Goldberg. P.K., \& Pavcnik, N. (2007). Distributional Effects of Globalization in Developing Countries. Journal of Economic Literature, 45(1), 39-82.

Jaumotte, F., Lall, S., \& Papageorgiou C. (2013). Rising Income Inequality: Technology, or Trade and Financial Globalization?. IMF Economic Review, 61(2), 271-09.

Krusell, P., Ohanian, L.E., Ríos-Rull J.-V., \& Violante G.L. (2000). Capital-Skill Complementarity and Inequality: A Macroeconomic Analysis. Econometrica, 68(5), 1029-53.

Pérez-Moreno, S., Angulo-Guerrero, M.J. (2016). Does Economic Freedom Increase Income Inequality? Evidence from the EU Countries. Journal of Economic Policy Reform, 19(4), 327-347.

Piketty, T., \& Saez E. (2013). Top Incomes and the Great Recession: Recent Evolutions and Policy Implications. IMF Economic Review, 61(3), 456-78.

Ravallion, M. (2001). Growth, Inequality and Poverty: Looking Beyond Averages. World Development, 29(11), 1803-15.

Sánchez-López, C., \& de Paz Báñez, M.A. (2016). Desigualdad y Pobreza en la Gran recesión. Diferencias entre los países de la UE. Economía Mundial, 44, 93-124.

Lang Valentin, F., \& Mendes Tavares Marina. (2018) The Distribution of Gains from Globalization. IMF Working Paper, 188/54, International Monetary Fund.

Vicente Villardón, J.L. (2014). Multiplot: A package for multivariate analysis using biplots. Departamento de Estadística. Universidad de Salamanca, 2014. Online in: http://biplot.usal.es/ClassicalBiplot/index.html.

Wade Robert, H. (2004). Is Globalization Reducing Poverty and Inequality?. World Development, 32(4), 567-589.

Winter, A., McCulloch, N., \& McKay A. (2004). Trade Liberalization and Poverty: The Evidence so Far. Journal of Economic Literature, 42(1), 72-115.

Winters, L.A., \& Martuscelli A. (2014). Trade Liberalization and Poverty: What have We Learned in a Decade?. Annual Review of Resource Economics, 6(1), 493-512. 


\section{Annex}

Table 1. Income inequality over the UE 2005-2015

\begin{tabular}{|c|c|c|c|c|c|c|c|c|c|c|c|c|}
\hline & 2005 & 2006 & 2007 & 2008 & 2009 & 2010 & 2011 & 2012 & 2013 & 2014 & 2015 & 2005-2015 \\
\hline $\mathrm{Au}$ & 26,30 & 25,30 & 26,20 & 27,70 & 7,50 & 28,30 & 27,40 & 27,60 & 27,00 & 27,60 & 27,20 & 0,90 \\
\hline Belgium & 28,00 & 27,80 & 26,30 & 27,50 & 26,40 & 26,60 & 26,30 & 26,50 & 25,90 & 25,90 & 26,20 & $-1,80$ \\
\hline Bulgaria & & 31,20 & 35,30 & 35,90 & 33,40 & 33,20 & 35,00 & 33,60 & 35,40 & 35,40 & 37,00 & 5,80 \\
\hline Croatia & & & & & & 1,60 & 31,20 & 30,90 & 0,90 & 0,20 & 30,40 & $-1,20$ \\
\hline Cyprus & 28,70 & 28,80 & 29,80 & 29,00 & 29,50 & 30,10 & 29,20 & 31,00 & 32,40 & 34,80 & 33,60 & 4,90 \\
\hline Czec & 26,00 & 25,30 & 25,30 & 24,70 & 25,10 & 24,90 & 25,20 & 24,90 & 24,60 & 25,10 & 25,00 & $-1,00$ \\
\hline & 3,90 & 23,70 & 25,20 & 25,10 & 26,90 & 26,90 & 26,60 & 26,50 & 26,80 & 27,70 & 7,40 &, 50 \\
\hline & 34,10 & 33,10 & 33,40 & 30,90 & 31,40 & 31,30 & 31,90 & 32,50 & 32,90 & 35,60 & 34,80 & 0,70 \\
\hline & 26,00 & 25,90 & 26,20 & 26,30 & 25,90 & 25,40 & 25,80 & 25,90 & 25,40 & 25,60 & 25,20 & $-0,80$ \\
\hline & 7,70 & 27,30 & 26,60 & 29,80 & 29,90 & 29,80 & 30,80 & 30,50 & 0,10 & 29,20 & 29,20 &, 50 \\
\hline & 26,10 & 26,80 & 30,40 & 30,20 & 29,10 & 29,30 & 29,00 & 28,30 & 29,70 & 30,70 & 30,10 & 4,00 \\
\hline & 33,20 & 34,30 & 34,30 & 33,40 & 33,10 & 32,90 & 33,50 & 34,30 & 34,40 & 34,50 & 34,20 & 00 \\
\hline $\mathrm{Hu}$ & 27,60 & 33,30 & 25,60 & 25,20 & 24,70 & 24,10 & 26,90 & 27,20 & 28,30 & 28,60 & 28,20 & 0,60 \\
\hline Irela & 31,90 & 31,90 & 31,30 & 29,90 & 28,80 & 30,70 & 29,80 & 30,50 & 30,70 & 31,10 & 29,80 & $-2,10$ \\
\hline Italy & 32,70 & 32,10 & 32,00 & 31,20 & 31,80 & 31,70 & 32,50 & 32,40 & 32,80 & 32,40 & 32,40 & $-0,30$ \\
\hline $\mathrm{La}$ & 36,20 & 38,90 & 35,40 & 37,50 & 37,50 & 35,90 & 35,10 & 35,70 & 35,20 & 35,50 & 35,40 & $-0,80$ \\
\hline Lith & 36,30 & 35,00 & 33,80 & 34,50 & 35,90 & 37,00 & 33,00 & 32,00 & 34,60 & 35,00 & 37,90 & 1,60 \\
\hline Luxembourg & 26,50 & 27,80 & 27,40 & 27,70 & 29,20 & 27,90 & 27,20 & 28,00 & 30,40 & 28,70 & 28,50 & 2,00 \\
\hline Malta & 27,00 & 27,10 & 26,30 & 28,10 & 27,40 & 28,60 & 27,20 & 27,10 & 27,90 & 27,70 & 28,10 & 1,10 \\
\hline Netl & 26,90 & 26,40 & 27,60 & 27,60 & 27,20 & 25,50 & 25,80 & 25,40 & 25,10 & 26,20 & 26,70 & $-0,20$ \\
\hline Nor & 28,20 & 29,20 & 23,70 & 25,10 & 24,10 & 23,60 & 22,90 & 22,50 & 22,70 & 23,50 & 23,90 & $-4,30$ \\
\hline Poland & 35,60 & 33,30 & 32,20 & 32,00 & 31,40 & 31,10 & 31,10 & 30,90 & 30,70 & 30,80 & 30,60 & $-5,00$ \\
\hline Portl & 38,10 & 37,70 & 36,80 & 35,80 & 35,40 & 33,70 & 34,20 & 34,50 & 34,20 & 34,50 & 34,00 & $-4,10$ \\
\hline Romania & & & 38,30 & 35,90 & 34,50 & 33,50 & 33,50 & 34,00 & 34,60 & 35,00 & 37,40 & $-0,90$ \\
\hline Slovakia & 26,20 & 28,10 & 24,50 & 23,70 & 24,80 & 25,90 & 25,70 & 25,30 & 24,20 & 26,10 & 23,70 & $-2,50$ \\
\hline Sloven & 23,80 & 23,70 & 23,20 & 23,40 & 22,70 & 23,80 & 23,80 & 23,70 & 24,40 & 25,00 & 24,50 & 0,70 \\
\hline Spain & 32,20 & 31,90 & 31,90 & 32,40 & 32,90 & 33,50 & 34,00 & 34,20 & 33,70 & 34,70 & 34,60 & 2,40 \\
\hline Sweden & 23,40 & 24,00 & 23,40 & 24,00 & 24,80 & 24,10 & 24,40 & 24,80 & 24,90 & 25,40 & 25,20 & 1,80 \\
\hline \multirow[t]{2}{*}{ United Kingdom } & 34,60 & 32,50 & 32,60 & 33,90 & 32,40 & 32,90 & 33,00 & 31,30 & 30,20 & 31,60 & 32,40 & $-2,20$ \\
\hline & 29,51 & 29,72 & 29,46 & 29,59 & 29,42 & 29,44 & 29,38 & 29,38 & 29,66 & 30,14 & 30,12 & 0,62 \\
\hline
\end{tabular}

Source. Eurostat 
Table 2. Main descriptive statistics by cluster

\begin{tabular}{|c|c|c|c|c|c|c|c|}
\hline CLUSTER & & $\mathrm{N}^{\mathrm{o}}$ & Range & Minimum & Maximum & Mean & $\begin{array}{l}\text { Standard } \\
\text { deviation }\end{array}$ \\
\hline \multirow[t]{8}{*}{ Cluster 1} & Income inequality & 8 & 8.1 & 24.4 & 32.5 & 27.0 & 2.7 \\
\hline & Export-to-GDP ratio & 8 & 46.9 & 27.6 & 74.5 & 47.1 & 13.5 \\
\hline & Import-to-GDP ratio & 8 & 36.4 & 28.8 & 65.3 & 41.9 & 11.7 \\
\hline & $\begin{array}{l}\text { Ratio of exports and imports to } \\
\text { GDP }\end{array}$ & 8 & 0.5 & 0.9 & 1.4 & 1.1 & 0.1 \\
\hline & Ratio of ICT sector to GDP & 8 & 3.2 & 3.3 & 6.5 & 4.9 & 1.2 \\
\hline & Inward FDI & 8 & 33.1 & 2.4 & 35.5 & 8.2 & 11.1 \\
\hline & Outward FDI & 8 & 30.1 & 1.3 & 31.4 & 6.6 & 10.1 \\
\hline & $\mathrm{N}^{\mathrm{o}}$ valid (by list) & 8 & & & & & \\
\hline \multirow[t]{8}{*}{ Cluster 2} & Income inequality & 6 & 7.2 & 26.7 & 33.8 & 31.0 & 2.7 \\
\hline & Export-to-GDP ratio & 6 & 53.2 & 25.3 & 78.5 & 40.1 & 21.8 \\
\hline & Import-to-GDP ratio & 6 & 49.9 & 26.7 & 76.7 & 42.0 & 20.5 \\
\hline & $\begin{array}{l}\text { Ratio of exports and imports to } \\
\text { GDP }\end{array}$ & 6 & 0.2 & 0.8 & 1.0 & 0.9 & 0.1 \\
\hline & Ratio of ICT sector to GDP & 5 & 2.2 & 2.3 & 4.5 & 3.6 & 0.8 \\
\hline & Inward FDI & 6 & 10.1 & 0.8 & 10.9 & 5.0 & 4.1 \\
\hline & Outward FDI & 6 & 11.8 & 0.9 & 12.6 & 4.3 & 4.6 \\
\hline & $\mathrm{N}^{\mathrm{o}}$ valid (by list) & 5 & & & & & \\
\hline \multirow[t]{8}{*}{ Cluster 3} & Income inequality & 12 & 12.4 & 23.8 & 36.2 & 31.1 & 4.6 \\
\hline & Export-to-GDP ratio & 12 & 49.8 & 33.4 & 83.2 & 58.6 & 17.7 \\
\hline & Import-to-GDP ratio & 12 & 45.3 & 38.2 & 83.5 & 60.2 & 15.7 \\
\hline & $\begin{array}{l}\text { Ratio of exports and imports to } \\
\text { GDP }\end{array}$ & 12 & 0.2 & 0.9 & 1.1 & 1.0 & 0.1 \\
\hline & Ratio of ICT sector to GDP & 12 & 3.5 & 2.5 & 6.0 & 4.0 & 1.0 \\
\hline & Inward FDI & 12 & 9.4 & 0.1 & 9.5 & 2.1 & 2.6 \\
\hline & Outward FDI & 12 & 9.6 & 1.7 & 11.3 & 5.0 & 3.3 \\
\hline & $\mathrm{N}^{\mathrm{o}}$ valid (by list) & 12 & & & & & \\
\hline
\end{tabular}

